\title{
TMOD3/CYP19A1 Fusion Gene
}

National Cancer Institute

\section{Source}

National Cancer Institute. TMOD3/CYP19A1 Fusion Gene. NCI Thesaurus. Code C99689.

A fusion gene that results from a chromosomal inversion within 15q21.2-q21.3 and places the promoter for the TMOD3 gene near the 5 ' end of the CYP19A1 gene. This fused gene causes increased expression of the CYP19A1 gene and is associated with aromatase excess syndrome. 